\title{
THE USE OF BLENDED LEARNING TECHNOLOGY IN THE TRAINING FOR STUDENTS OF PEDAGOGICAL SPECIALTIES
}

\author{
A UTILIZAÇÃO DA TECNOLOGIA DE APRENDIZAGEM HÍBRIDA NA FORMAÇÃO \\ DOS ESTUDANTES DE ESPECIALIDADES PEDAGÓGICAS
}

\author{
EL USO DE LA TECNOLOGÍA BLENDED LEARNING EN LA FORMACIÓN DE LOS \\ ESTUDIANTES DE LAS ESPECIALIDADES PEDAGÓGICAS
}

\author{
Larysa UDOVYCHENKO ${ }^{1}$ \\ Nataliia KUZMINETS ${ }^{2}$ \\ Olena STADNIK ${ }^{3}$ \\ Natalia KOSHARNA ${ }^{4}$ \\ Lada PETRYK ${ }^{5}$
}

\begin{abstract}
This study aims to establish the effectiveness of the use of blended learning technology, its impact on the success of higher education applicants, and the quality of education in general. Additionally, the pedagogical technology was evaluated by the participants of the educational process. The main methods are pedagogical experiment and interviewing for theoretical research using descriptive methods, synthesis and analysis. The main hypothesis is that blended learning is an effective, convenient, and efficient pedagogical technology, which is a necessary component of modern university education. The result of the pedagogical experiment should establish the level of blended education technology effectiveness for students of pedagogical specialties in the conditions of the modern educational paradigm. In the future, it is worth continuing to develop the innovative concept of blended learning in educational practice in a harmonious combination of online and offline learning.
\end{abstract}

KEYWORDS: Blended learning. Traditional learning. Computer assisted learning.

\footnotetext{
${ }^{1}$ Borys Grinchenko Kyiv University (KUBG), Kyiv - Ukraine. Associate Professor of the Department of Ukrainian Literature. Doctor of Pedagogical Sciences. ORCID: https://orcid.org/0000-0002-5698-557X. E-mail: 1.udovychenko@kubg.edu.ua

${ }^{2}$ Vinnytsia Mykhailo Kotsiubynskyi State Pedagogical University (VSPU), Vinnytsia - Ukraine. Associate Professor, Institute of History, Ethnology and Right, Department of History and Culture of Ukraine. PhD in History. ORCID: https://orcid.org/0000-0001-9939-2451. E-mail: 1974natalika1@gmail.com

${ }_{3}^{3}$ Vinnytsia Mykhailo Kotsiubynskyi State Pedagogical University (VSPU), Vinnytsia - Ukraine. Docent, Institute of History, Ethnology and Right, Department of History and Culture of Ukraine. Candidate of Historical Sciences. ORCID: https://orcid.org/0000-0002-9554-6975. E-mail: elenast.mail@gmail.com

${ }^{4}$ Borys Grinchenko Kyiv University (KUBG), Kyiv - Ukraine. Associate Professor, Foreign Languages and Methodology Department, Pedagogical Institute. Candidate of Pedagogical Sciences. ORCID: https://orcid.org/0000-0003-4841-6219. E-mail: n.kosharna@kubg.edu.ua

${ }^{5}$ Borys Grinchenko Kyiv University (KUBG), Kyiv - Ukraine. Senior lecturer of Foreign Languages and Methodology Department, Pedagogical Institute, Foreign Languages and Methodology Department. Candidate of Pedagogical Sciences. ORCID: https://orcid.org/0000-0001-9936-176X. E-mail: 1.petryk@kubg.edu.ua
}

RPGE- Revista on line de Política e Gestão Educacional, Araraquara, v. 25, n. 3, p. 2258-2271, Sep./Dec. 2021. e-ISSN: 1519-9029 DOI: https://doi.org/10.22633/rpge.v25i2.15958 
RESUMO: Este estudo visa estabelecer a eficácia da utilização da tecnologia de aprendizagem híbrida, seu impacto no sucesso dos candidatos ao ensino superior e a qualidade do ensino em geral. Além disso, a tecnologia pedagógica foi avaliada pelos participantes do processo educativo. Os principais métodos são o método da experiência pedagógica e a entrevista para pesquisa teórica utilizando métodos descritivos, síntese e análise. A hipótese principal é que a aprendizagem híbrida é uma tecnologia pedagógica eficaz, conveniente e eficiente, e uma componente necessária da educação universitária moderna. O resultado da experiência pedagógica deve estabelecer o nível de eficácia da tecnologia da educação híbrida para os estudantes de especialidades pedagógicas nas condições do paradigma educacional moderno. No futuro, vale a pena continuar a desenvolver o conceito inovador de aprendizagem hibrida na prática educacional, numa combinação harmoniosa de aprendizagem online e offline.

PALAVRAS-CHAVE: Aprendizagem hibrida. Aprendizagem tradicional. Aprendizagem assistida por computador.

RESUMEN: Este estudio pretende establecer la eficacia del uso de la tecnología de aprendizaje combinado, su impacto en el éxito de los aspirantes a la educación superior y la calidad de la educación en general. Los métodos principales son el método del experimento pedagógico y la entrevista para la investigación teórica con métodos descriptivos, de sintesis $y$ de análisis. La hipótesis principal es que el aprendizaje combinado es una tecnología pedagógica eficaz, conveniente y eficiente, que es un componente necesario de la educación universitaria moderna. El resultado del experimento pedagógico debería establecer el nivel de eficacia de la tecnología de educación combinada para los estudiantes de las especialidades pedagógicas en las condiciones del paradigma educativo moderno. En el futuro, vale la pena seguir desarrollando el concepto innovador de la educación combinada en la práctica educativa en una combinación armoniosa de aprendizaje en línea y fuera de linea.

$\boldsymbol{P A L A B R A S ~ C L A V E : ~ A p r e n d i z a j e ~ c o m b i n a d o . ~ A p r e n d i z a j e ~ t r a d i c i o n a l . ~ A p r e n d i z a j e ~ a s i s t i d o ~}$ por ordenador.

\section{Introduction}

The use of blended learning technology in the educational process is a hot topic for contemporary pedagogical thought and is often seen as part of higher education development strategy (BOELENS; WEVER; VOET, 2017; FINDIK; OZKAN, 2013). Practice-centered ways and methods of blended learning are presented in the best educational platforms (KOSTIKOVA et al., 2019; YILMAZ, 2016). It is a set of methods, exercises, technologically supported forms of learning, which are designed to develop and provide a strategy for positive thinking, professional growth, digital literacy, should guide learning processes, the ability to navigate crisis conditions, and solve problems of various nature. 
Blended learning is considered by many researchers as an innovative concept, attracts the advantages of traditional teaching methods combined with the possibilities of information and communication technologies, uses the possibilities of offline and online learning.

Blended learning as a technology has the potential for an integrated approach, simulated learning, involving the capabilities of computer technology. In blended learning, there are several prerequisites for success: thorough preparation, large budgets and setting of all participants of training for success, motivation to work, readiness to master new educational approaches, and methods of work. The use of different modes, forms of communication training also dictate the complexity of planning, organization, and implementation of the educational process involves good technical training and a strong material and technical base (CAVUS; IBRAHIM, 2017; KARPUSHYNA et al., 2019). Blended learning can be thought of as a formal education methodology where students work on part of the learning material in classrooms and laboratories and work through the other part on their own at a time and way that is convenient for them, where the pace of learning is chosen directly by the student. All methods and forms used during the implementation of blended learning should be logically connected and students should receive a holistic learning experience. In the context of blended learning, the use of the Internet is necessary, otherwise, it will not be possible to obtain the desired learning outcomes. In this article, we took a look at the use of high-tech tools in the learning process and their impact on learning through the lens of contextuality and cognition.

This study aimed to establish the effectiveness of blended learning technology in the training of pedagogical specialties students, as well as the nature of the blended technology impact on the success of applicants for education and the creation of a positive climate in the educational environment.

Based on the goal, it is planned to perform the following research tasks: to establish the impact of blended learning technology on the success and attendance of students of pedagogical specialties; and to determine how well the participants of the educational process approve of the introduction of blended learning and are interested in further work with it. 


\section{Materials and methods}

The study used methods of analysis and synthesis, as well as observation and questioning. The main method was the method of pedagogical experiment. The research team collected and analyzed the data, which is subsequently planned to be used as answers to the questions posed in the study.

The experimental study was conducted in the 2020/2021 academic year, during the first semester. The experiment involved 80 students of the Kharkiv National Pedagogical University named after Hryhoriy Skovoroda, who studied in the second year of the first (bachelor) level of education in pedagogical specialties (specialty 014 "Secondary education. Language and Literature (English)"; specialty 013 “Elementary education”). All students who agreed to participate in the research project were combined into four groups. Two of them were chosen as experimental (EG1 studied in specialty 014, EG2 belonged to major 013). These groups, during the reading of the educational discipline "Foreign language", actively used the technology of blended learning, which was carried out in quarantine conditions associated with the pandemic coronavirus.

For second control groups (CG3 studied in specialty 014, and CG4 belonged to the specialty 013) on the same academic discipline, which was not provided for the use of blended learning technology, everything happened per the educational mode and settings dictated by the introduction of quarantine.

The research experiment provided for the implementation of the project in phase III. At the first stage, preparation of the teaching staff for the implementation of blended learning created educational materials adapted to the technology of blended learning, prepared the necessary material and technical base.

During the second stage and at the end of the staging experiment, the measurements of the respondent students' knowledge were made (the total average score of the students' learning outcomes according to the 100-point system was determined). Also, at the end of the project (third stage), a questionnaire survey was organized for EG1 and EG2, in which students' answers about their attitude towards blended learning technology and the feasibility of their continuation were collected. Throughout all stages of the experiment, there was constant monitoring of student attendance in all study groups.

At the third stage, the final analysis of the received results took place. The data were processed so that it could be presented as a basis for defining the level of effectiveness of the technology, answering the problematic questions of the research. The results of the 
experiment are presented in the form of a description of statistics, the data of the questionnaire were taken into account.

All respondents participated in the experiment voluntarily, and the research team guaranteed the anonymity of the surveys, as well as the fact that the personal information obtained during the research will not be made public by the research team.

\section{Literature review}

The modern pedagogy actively discusses the concept of blended learning (GENG; LAW; NIU, 2019), its main features and conditions of implementation in educational practice, stipulates the spheres and areas of application.

Many publications consider the components of blended learning methods and their integrated use in different educational systems (BROADBENT, 2017; IVANOVA; MOSENKIS; STROKAL, 2020). There are explorations in which the idea of blended learning is presented as one of the basic and vital for modern education. It is an integral part of modern university education if it wants to be quality and competitive in the educational services market.

Pedagogy already has several successful examples of blended learning based on teaching practices in higher education (RABABAH, 2020; SALGUR, 2013). Blended learning is often used in the preparation of future teachers, and in foreign language studies. Also, it is used in literary and managerial studies, as well as in linguistics and law, where interactive teaching methods are needed (KARPUSHYNA et al., 2019; PATIL, 2008; VYKHRUSHCH et al., 2019). These trends have been particularly strong during the pandemics, where learning conditions have dictated the introduction of blended technology.

Practical projects using blended learning technology have been investigated, analyzed, and made sense of in some works (PORTER et al., 2016) highlighted several conditions on which the success of the project depends: the formation of an effective learning climate; having flexibility in the choice of methods and forms of teaching; facilitating learning conditions and promoting, improving the interaction between students (BOELENS; WEVER; VOET, 2017; KO; SAMMONS; BAKKUM, 2013).

Some studies have been dedicated to identifying the difficulties encountered in the blended learning technology application, a set of factors, sometimes related to the familiar educational space of traditional learning models, and require no additional effort (MASON, 2006). 
Researchers (HONG et al., 2014) found that college students' positive attitudes and approval of blended learning technology positively influenced their intentions to engage in digital and online learning opportunities. A study of blended learning use in a natural field has earned high praise from faculty and students (BRENT, 2015). Moreover, the use of online course materials can improve students' intellectual abilities (SIM; POP, 2014).

\section{Results}

The blended learning model proposed in the study should take into account the presence of prerequisites and coherence between readiness for independent learning, digital literacy of all participants in the learning process, and the motivation of students. Schematically, this structure can be represented as follows (Figure 1).

Figure 1 - Motivation used of blended learning

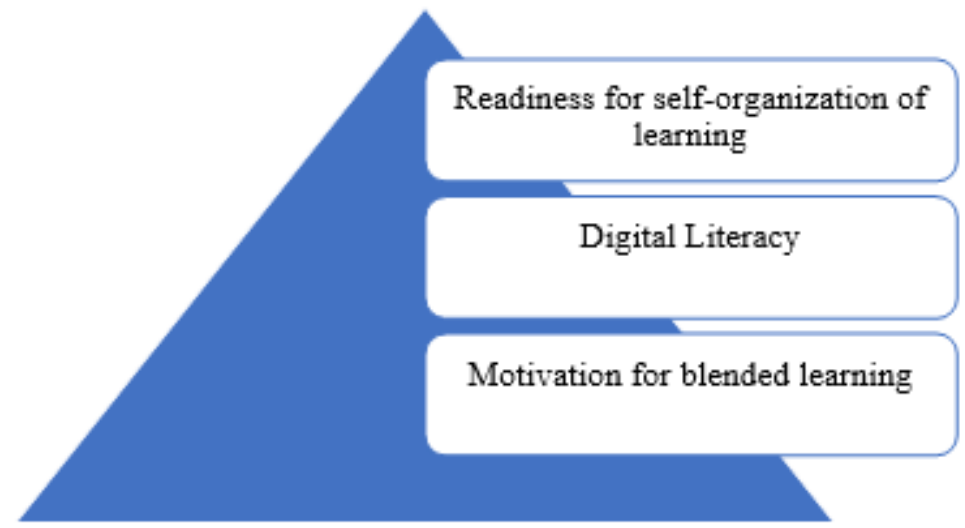

Source: Prepared by the authors

Students who are ready to learn on their own actively engage in blended learning and can adopt appropriate educational strategies per the educational content. Digital literacy is dictated by the need to use successfully an educationally technology-rich learning environment. It can give the student more perspectives and opportunities for independent learning. Blended learning context offers students an open communication with teachers and colleagues, where it is possible to discuss complex topics and issues, there was self-monitored access to all kinds of learning content, has the task to increase students' interest in blended learning, increase their motivation for learning material. 
The structure of technology of the blended training was applied in an experiment it is possible to present through the description of components communicative forms of the project (Figure 2).

Figure 2 - The structure of technology of the blended training

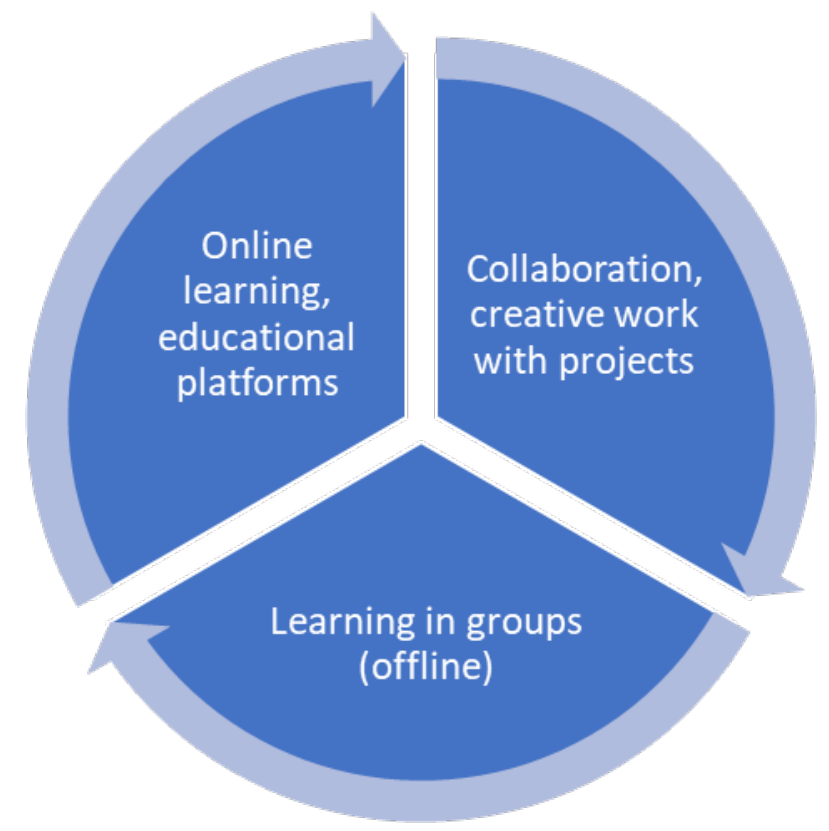

Source: Prepared by the authors

At the first stage of the project, which coincides with the beginning of the first semester, training of teachers participating in the experiment was conducted, additional consultations with technical staff were held as well as formed curricula and training materials were prepared to take into account the specifics of blended learning technology. The fate of independent work of educational material, viewing audiovisual materials on an individual schedule determined by the student was determined. During the application of blended learning students, who have a high level of self-orientation, the ability to self-education, and its planning, are actively involved in learning activities on social educational platforms, resources of the Internet. All respondents are easily oriented in the educational process, well attuned to business communication. Students attuned to self-improvement should be ready to achieve learning goals.

In the second stage of the project, the first control work was carried out to measure the level of the overall performance of the respondents, as well as to determine the level of attendance in all groups of students who participated in the experiment (Table 1).

Table 1 - Assessment of the level of success in the experimental and control groups (Stage II)

RPGE- Revista on line de Política e Gestão Educacional, Araraquara, v. 25, n. 3, p. 2258-2271, Sep./Dec. 2021. e-ISSN: 1519-9029 DOI: https://doi.org/10.22633/rpge.v25i2.15958 


\begin{tabular}{|l|c|c|c|c|}
\hline & Unsatisfactory & Satisfactory & Good & Excellent \\
\hline EG1 & $6 \%$ & $33 \%$ & $46 \%$ & $15 \%$ \\
\hline EG2 & $7 \%$ & $35 \%$ & $40 \%$ & $18 \%$ \\
\hline CG3 & $7 \%$ & $37 \%$ & $42 \%$ & $15 \%$ \\
\hline CG4 & $8 \%$ & $37 \%$ & $40 \%$ & $15 \%$ \\
\hline
\end{tabular}

Source: Prepared by the authors

As we can see, the success rate in the experimental group after passing half of the "Foreign Language" discipline is higher than in the control group as a whole by $2 \%$. The highest number of positive evaluations was in EG1 (61\%) and EG2 (58\%). The second stage involved the extension of the blended learning technology use in teaching the experimental groups a foreign (English) language. Also was conducted a control measurement of the students' performance in learning, identified changes in it. At the final stage, at the end of the first-semester students' success was defined through final control task grades (Table 2).

After completing the training course in foreign (English) language more grades "good" and "excellent" were obtained by the students of the experimental groups. By 7\% the results of the respondents from EG1 and EG two were improved, while in CG3 and CG4 the success in general increased by an average of $3 \%$.

Table 2 - Assessment of the success level in the experimental and control groups at the end of the project

\begin{tabular}{|l|c|c|c|c|}
\hline & Unsatisfactory & Satisfactory & Good & Excellent \\
\hline EG1 & $5 \%$ & $29 \%$ & $51 \%$ & $15 \%$ \\
\hline EG2 & $6 \%$ & $30 \%$ & $45 \%$ & $19 \%$ \\
\hline CG3 & $7 \%$ & $36 \%$ & $43 \%$ & $15 \%$ \\
\hline CG4 & $8 \%$ & $35 \%$ & $41 \%$ & $16 \%$ \\
\hline
\end{tabular}

Source: Prepared by the authors 
The final assessment consisted of a number of indicators. These were achievement scores. The control tests measured the level of foreign language proficiency and readiness to communicate. Successful engagement of the respondent in blended learning is an indicator of the level of motivation, digital literacy, ability to self-reflection, and self-control. At the final stage, there was also an analysis of the respondents' attendance during the continuation of the pedagogical experiment. An indicative criterion for the adoption of blended technology is the results of class attendance (the table shows the total number of students in the group (20 students in each one).

At the final stage, all respondents were offered a questionnaire that contained a number of questions related to the evaluation of blended learning technology introduced for students of pedagogical specialties. Closed answers required a choice of "yes" or "no". The results were presented as a percentage.

In the application of blended learning technology, students should focus on the achievement of a range of skills and competencies, and assess how important, useful, and interesting the opportunities and perspectives gained were for the respondents. There are seven questions for the consideration of the respondents (Table 3).

Figure 3 - Students' attendance schedule of the academic discipline "Foreign language"

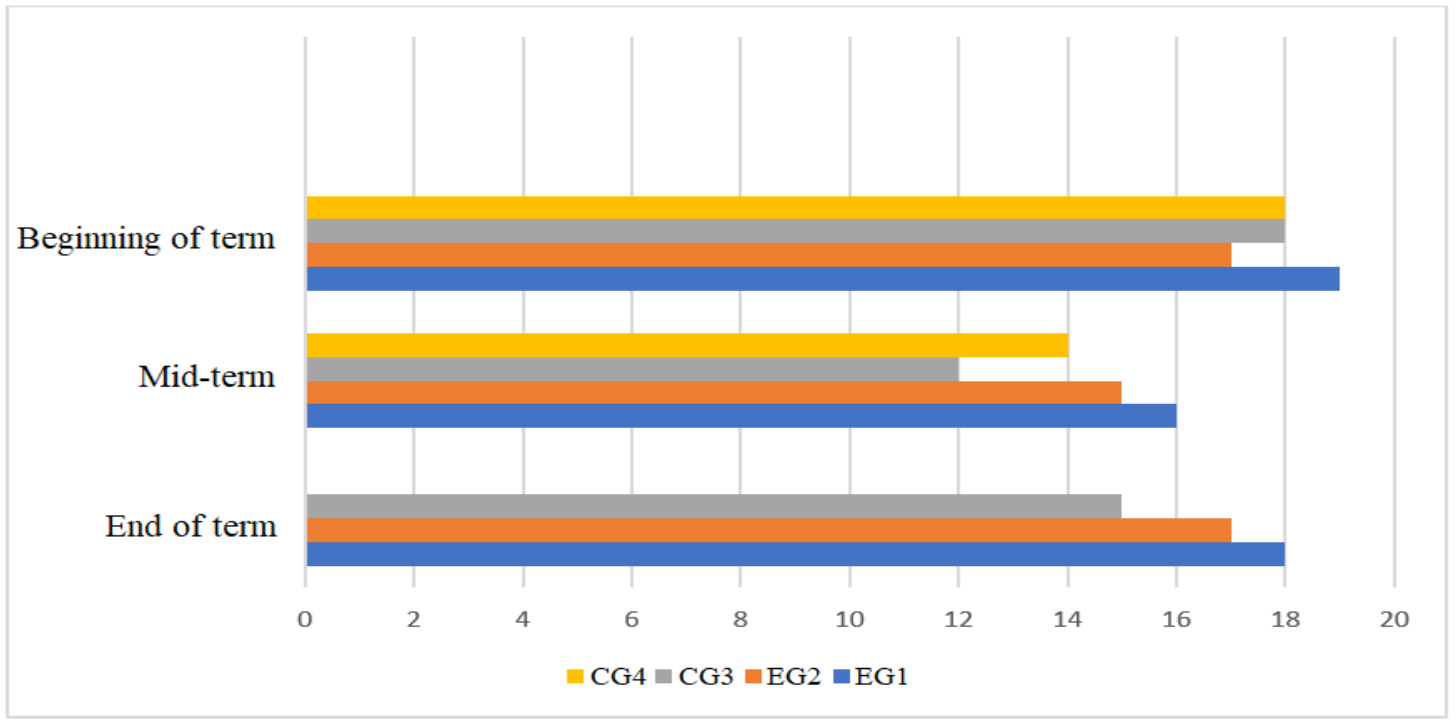

Source: Prepared by the authors 
Table 3 - Questionnaire on participants' evaluation of blended learning technology

\begin{tabular}{|l|c|c|}
\hline Indicators & $\begin{array}{c}\text { EG1 } \\
\text { yes }\end{array}$ & $\begin{array}{c}\text { EG2 } \\
\text { yes }\end{array}$ \\
\hline Blended technologies require increased proficiency in information technology & $32 \%$ & $34 \%$ \\
\hline Self-regulation of learning activities is essential & $57 \%$ & $59 \%$ \\
\hline Blended learning is a convenient learning technology & $68 \%$ & $67 \%$ \\
\hline Blended learning improves the quality of education & $38 \%$ & $42 \%$ \\
\hline This technology requires more effort & $60 \%$ & $59 \%$ \\
\hline Blended learning should continue to be used in the future & $81 \%$ & $73 \%$ \\
\hline
\end{tabular}

Source: Prepared by the authors

Based on the results of the questionnaire, we can say that a positive assessment of their ability to participate in blended learning, willingness to use high technology, opportunities of educational learning platforms and social networks, self-critical attitude to themselves, and motivation to learn in most members of the experimental groups is on average $10 \%$. Blended learning technologies provide an opportunity to realize learning potential, increase the level of digital literacy, independent work skills, determination, self-criticism, and planning of the learning process, improve their communication competence.

\section{Discussion}

The existence of various online learning technologies, such as online discussion forums, provides continuous feedback between education applicants and academic staff (GENG; LAW; NIU, 2019; STOCKWELL et al., 2015). In this way, the traditional classroom and laboratory learning integration with online learning provides asynchronous and collaborative learning for students (VANSLAMBROUCK et al., 2018). Indeed, this research has shown that comprehending the balance between classroom and online learning is essential to the effectiveness of blended learning because students value and find context with the instructor, direct communication in a blended learning process is necessary.

Also, in several studies that looked at the implementation of effective technologies (FINDIK; OZKAN, 2013; JONES, 1999; MTEBE; RAISAMO, 2014), it was determined that three key factors that determine the success of blended learning application are the presence of a clear strategy, structured learning process, material and idea support of the project by all participants in the educational process. We found that innovation strategies affect respondents' evaluation of the quality of university education, with the management of the 
higher education institution being responsible for facilitating or hindering the implementation and adoption of technology (KIKI-PAPADAKIS; CHAIMALA, 2016; PORTER et al., 2016) of learning. Our study reveals that the implementation of educational innovation also depends on an institutional component such as faculty and students. They also determine the key factors, prerequisites, and level of interest in this learning technology, its successful implementation. All necessary conditions of blended learning implementation (organizational readiness, material, and technical base, related technical and human resources, professional development of the teacher, readiness, and approval of the students) should be provided in the conditions of university education.

\section{Conclusions}

In general, the results of this experiment indicate that blended learning technology actively uses the capabilities of digital technology and online learning environments, stimulate interest in topics, abilities, skills, and theoretical knowledge in parallel with the introduction of lectures, laboratory, and seminar classes and were more effective as a strategic educational direction in higher education than traditional approaches to the educational process. This is evidenced by the $7 \%$ increase in achievement of the groups where blended learning was applied, while the groups with traditional teaching success increased by $3 \%$. It should be noted that in addition to the increase in academic achievement, the percentage of students satisfied with this technology of teaching also increased, as well student attendance in the experimental groups by $20 \%$, while in traditional conditions, attendance remained at the same mark.

Providing a part of the material for independent familiarization at a convenient time and place for the applicant of education, the audience frees up time for practical and creative tasks, for active forms of learning, and solving complex issues that have arisen in the process of independent learning of the material. Thus, the technology of blended learning can have a positive impact on the quality of education and the motivation of students to study. The use of a set of different teaching methods, tools, digital technologies, electronic learning platforms, etc. in the learning process also contributes to the assimilation of learning material in such a way that the student in the future can apply the acquired knowledge, skills, and abilities in a new situation, use in professional activity, academic environment. All this demonstrates the effectiveness and quality of the learning process where blended learning technology is used. 
Active use of verbalization of mental activity of an individual in training and encouraging self-expression is important for successful learning and further career development. The educational system should contribute to the education of such values, the formation of positive citizens.

In the future, experimental research on the application of blended learning technology in research programs on the territory of university education. These results may illustrate the feasibility of the general use of the methodology of pedagogical experiment in the evaluation of innovative learning technologies, the appropriateness of the use of learning interference.

\section{REFERENCES}

BOELENS, R.; WEVER, B.; VOET, M. Four key challenges to the design of blended learning: A systematic literature review. Educational Research Review, Regensburg, v. 22, p. 1-18, 2017. DOI: https://doi.org/10.1016/j.edurev.2017.06.001

BROADBENT, J. Comparing online and blended learner's self-regulated learning strategies and academic performance. The Internet and Higher Education, Hong Kong, v. 33, p. 2432, 2017. DOI: https://doi.org/10.1016/j.iheduc.2017.01.004

CAVUS, N.; IBRAHIM, D. Learning English using children's stories in mobile devices. British Journal of Educational Technology, Manchester, v. 48, n. 2, p. 625-641, 2017. DOI: https://doi.org/10.1111/bjet.12427

FINDIK, C.; OZKAN, S. A model for instructors' adoption of learning management systems: empirical validation in higher education context. Turkish Online Journal of Educational Technology, Sakarya, v. 12, n. 2, p. 13-25, 2013. Available: http://tojet.net/articles/v12i2/1222.pdf. Access: 14 Oct. 2021.

GENG, S.; LAW, K. M. Y.; NIU, B. Investigating self-directed learning and technology readiness in blending learning environment. International Journal Education Technology High Education, Barcelona, v. 16, 2019. DOI: https://doi.org/10.1186/s41239-019-0147-0

HONG, J.-C. et al. Using a "prediction-observation-explanation" inquiry model to enhance student interest and intention to continue science learning predicted by their Internet cognitive failure. Computers \& Education, Tempe, v. 72, p. 110-120, 2014. DOI:

https://doi.org/10.1016/j.compedu.2013.10.004

IVANOVA, I.; MOSENKIS, I. L.; STROKAL, O. M. Modern media pedagogy: Ways of forming public journalism in Ukraine. Asia Life Sciences, v. 22, n. 2, p. 357-370, 2020. Available: http://repository.hneu.edu.ua/handle/123456789/24918. Access: 20 Sept. 2021.

JONES, J. F. From silence to talk: Cross-cultural ideas on students participation in academic group discussion. English for Specific Purposes, Atlanta, v. 18, n. 3, p. 243-259, 1999. DOI: https://doi.org/10.1016/S0889-4906(97)00059-8 
KARPUSHYNA, M. et al. Creating meaningful foreign language environment by means of content-based starters. Universal Journal of Educational Research, San Jose, v. 7 n. 12, p. 2710-2716, 2019. DOI: https://doi.org/10.13189/ujer.2019.071219

KIKI-PAPADAKIS, K.; CHAIMALA, F. The embedment of responsible research and innovation aspects in European science curricula. Revista Românească pentru Educaţie Multidimensională, v. 8, n. 2, p. 71-87, 2016. DOI:

https://doi.org/10.18662/rrem/2016.0802.06

KO, J.; SAMMONS P.; BAKKUM, L. Effective Teaching: a review of research and evidence. Reading: CfBT Education Trust, 2013.

KOSTIKOVA, I. et al. Teaching English speaking for FCE: using Facebook as a tool of instructional practice. Amazonia Investiga, Florencia, v. 8, n. 22, p. 719-727, 2019.

Available: https://amazoniainvestiga.info/index.php/amazonia/article/view/825/773. Access: 20 Sept. 2021.

MASON, R. Learning technologies for adult continuing education. Studies in Continuing Education, Sydney, v. 28, n. 2, p. 121-133, 2006. DOI:

https://doi.org/10.1080/01580370600751039

MTEBE, J. S.; RAISAMO, R. Challenges and instructors' intention to adopt and use open educational resources in higher education in Tanzania. The International Review of Research in Open and Distributed Learning, Athabasca, v. 15, n. 1, p. 249-271, 2014. DOI: https://doi.org/10.19173/irrodl.v15i1.1687

PATIL, Z. N. Rethinking the objectives of teaching English in Asia. Asian EFL Journal, Niigata, v. 10, n. 4, p. 227-240, 2008. Available: https:/www.asian-efl-journal.com/maineditions-new/rethinking-the-objectives-of-teaching-english-in-asia/index.htm. Access: 2 Sept. 2021.

PORTER, W. W. et al. A qualitative analysis of institutional drivers and barriers to blended learning adoption in higher education. The Internet and Higher Education, Hong Kong, v. 28, p. 17-27, 2016. DOI: https://doi.org/10.1016/j.iheduc.2015.08.003

RABABAH, I. H. M. The reality of using modern teaching methods in teaching Arabic for speakers of other languages from teachers' perspective. Journal of Social Sciences, Houston, v. 9, n. 1, p. 58-94, 2020. DOI: https://doi.org/10.25255/jss.2020.9.1.58.94

SALGUR, S. A. The importance of the teacher in intercultural education. International Journal of Global Education, Famagusta, v. 2, n. 1, p. 1-5, 2013. Available: http://www.ijge.net/index.php/ijge/article/view/41. Access: 20 Sept. 2021.

SIM, M.; POP, A. The impact of social media on vocabulary learning: Case study Facebook. Annals of the University of Oradea. Economic Science Series, v. 23, n. 2, p. 120-130, 2014. Available: https://ideas.repec.org/a/ora/journl/v2y2014i2p120-130.html. Access: 20 Sept. 2021.

STOCKWELL, B. et al. Blended Learning Improves Science Education. Cell, Cambridge, v. 162, n. 5, p. 933-936, 2015. DOI: https://doi.org/10.1016/j.cell.2015.08.009

RPGE- Revista on line de Política e Gestão Educacional, Araraquara, v. 25, n. 3, p. 2258-2271, Sep./Dec. 2021. e-ISSN: 1519-9029 
VANSLAMBROUCK, S. et al. Students' motivation and subjective task value of participating in online and blended learning environments. The Internet and Higher Education, Hong Kong, v. 36, p. 33-40, 2018. DOI:

https://doi.org/10.1016/j.iheduc.2017.09.002

VYKHRUSHCH, A. V. et al. Development of information culture of students of humanitarian specialities. Information Technologies and Learning Tools, Kyiv, v. 72, n. 4, p. 152-167, 2019. DOI: https://doi.org/10.33407/itlt.v72i4.2922

YILMAZ, R. Knowledge sharing behaviors in e-learning community: Exploring the role of academic self-efficacy and sense of community. Computers in Human Behavior, Quebec, v. 63, p. 373-382, 2016. DOI: https://doi.org/10.1016/j.chb.2016.05.055

\section{How to reference this article}

UDOVYCHENKO, L.; KUZMINETS, N.; STADNIK, O.; KOSHARNA, N.; PETRYK, L. The use of blended learning technology in the training for students of pedagogical specialties. Revista online de Política e Gestão Educacional, Araraquara, v. 25, n. 3, p. 2258-2271, Sep./Dec. 2021. e-ISSN: 1982-5587. DOI: https://doi.org/10.22633/rpge.v25i2.15958

Submitted: 18/09/2021

Required revisions: $20 / 10 / 2021$

Approved: 19/11/2021

Published: 08/12/2021 